\title{
Co-variation of sinking rate and cell quota among nutrient replete marine phytoplankton
}

\author{
P. K. Bienfang ${ }^{1}$ and P. J. Harrison ${ }^{2}$ \\ ${ }^{1}$ Oceanic Institute, Waimanalo, Hawaii 96795, USA \\ ${ }^{2}$ Department of Botany and Oceanography, University of British Columbia, Vancouver, B. C. V6T 2B1, Canada
}

\begin{abstract}
Relationships between sinking rate $(\psi)$ and carbon cell ${ }^{-1}$, nitrogen cell ${ }^{-1}$, and volume cell ${ }^{-1}$ were examined for 29 species of phytoplankton. Sinking rates were linearly related to all 3 indices of cells size $(P<0.001)$. Sinking rates of nanoplankton-sized organisms (i.e. cell volumes $<5,000 \mathrm{\mu m}^{3}$ ) were low, $\bar{\psi}=0.15 \mathrm{~m} \mathrm{~d}^{-1}$, and similar among various species. Sinking rates of net plankton (i.e. cell volumes $>5,000 \mu^{3}$ ) ranged from 0.23 to $1.70 \mathrm{~m} \mathrm{~d}^{-1}$. Although the co-variation of $\psi$ with the carbon and nitrogen cell quotas is coincidental with these quota's variation with cell size, the relation is of practical interest because carbon and nitrogen are frequently budgeted in ecosystem models.
\end{abstract}

The dependence of sinking rate upon a number of factors - such as light (Eppley et al., 1967), cellular nutrition (Smayda and Boleyn, 1965; Eppley et al., 1967; Bienfang 1981a; Bienfang et al., 1982), cell size (Eppley et al., 1967; Smayda, 1970) and cell quota (Bienfang, 1981a) - has been studied previously. This work examines the co-variation of sinking rates with cell quotas and particle volumes for 29 species of marine phytoplankton. These organisms embrace a wide range of cell volumes, and all were examined under nutrient-replete conditions.

Most cultures (Table 1), were obtained from the Northeast Pacific Culture Collection (NEPCC) at the Department of Oceanography, University of British Columbia, Vancouver, Canada. The NEPCC number, the isolation site, and date are given elsewhere (Harrison et al., 1980). These cultures were grown in ES enriched artificial seawater (ESAW: Harrison et al., 1980). One liter batch cultures were grown at $15^{\circ} \mathrm{C}$ under cool-white fluorescent lamps (I = $100 \mu \mathrm{Em}^{-2} \mathrm{~s}^{-1}$ ), on a 14:10 light/dark (L:D) cycle. Other cultures were grown in filtered $(0.22 \mu \mathrm{m}$ Millipore) subtropical seawater, enriched with FCRG (Food Chain Research Group, Scripps Institution of Oceanographyl enrichment solution. Irradiance of 150 $\mu \mathrm{Em}^{-2} \mathrm{~s}^{-1}$ was provided by fluorescent lighting (Gen- eral Electric, Cool-white) on a 12:12 L:D cycle. Prior to measuring the sinking rates and chemical composition, the cultures were allowed to grow exponentially until their densities reached $>10^{4}$ and $10^{8}$ cells $1^{-1}$ for large- and small-celled species, respectively.

Sinking rates $(\psi)$ were determined in duplicate, using the homogeneous sampling method of Bienfang (1981b) called SETCOL. This procedure uses settling columns of known height that initially contain a uniform distribution of cells. All measurements were made during the dark period of the $\mathrm{L} / \mathrm{D}$ cycle. The population's empirical mean sinking rate $(\psi)$, then, is based upon the rate of change of the vertical distribution of biomass. A comparison of $\psi$ values acquired by this method has shown them to be equivalent $(\mathrm{P}<0.001)$ to the rates acquired by either the direct observation of cells (Smayda and Boleyn, 1965), or the fluorometric procedure (Titman, 1975; Bienfang et al., 1977) when rate values are computed similarly. The standard deviations about the means of replicate sinking rate measurements were generally $\leq 10 \%$ of $\bar{\psi}$. The method of Gordon (1969) was adapted for the use of Whatman GF/C glass fiber filters and employed with a Hewlett-Packard 185B CHN analyzer, for analysis of particulate carbon and nitrogen. Cell densities and volumes were determined with an inverted microscope equipped with an occular micrometer; cell dimensions were measured for $\sim 50$ cells in each case. For the 10 chain-forming species (Table 1), particle volume was determined by multiplying mean cell volume by the average number of cells per chain; the latter was determined by examination of 50 chains.

Sinking rates $\left(\mathrm{m} \mathrm{d}^{-1}\right)$ are plotted against the 3 indicies of cell size in Fig. $1 \mathrm{a}-\mathrm{c}$. The distributions are plotted on a semilog scale merely for convenience of illustration; the abscissae are expressed as $\log _{10}$ of the 3 cell-size indicies. The relationship between sinking 
Table 1. Chemical composition, cell volume and sinking rates $(\psi)$ of 29 species of marine phytoplankton. All species were obtained from the Northeast Pacific Culture collection except species designated $\left({ }^{*}\right)$ which were obtained from Scripps Institution of Oceanography, La Jolla, CA. Chain-forming species are designated ( $")$

\begin{tabular}{|c|c|c|c|c|c|}
\hline Group, species & $\begin{array}{c}\text { Carbon } \\
\left(\mathrm{pg} \text { cell } 1^{-1}\right)\end{array}$ & $\begin{array}{l}\text { Nitrogen } \\
\left.\text { (pg cell }{ }^{-1}\right)\end{array}$ & $\begin{array}{c}\mathrm{C} / \mathrm{N} \\
\text { (by atoms) }\end{array}$ & $\begin{array}{c}\text { Cell vol. } \\
(\mu \mathrm{m})^{3}\end{array}$ & $\begin{array}{c}\psi \\
\left(m d^{-1}\right)\end{array}$ \\
\hline \multicolumn{6}{|l|}{ Bacillariophyceae } \\
\hline Amphiprora paludosa & $1.9 \times 10^{1}$ & 3.0 & 7.2 & $7.3 \times 10^{1}$ & 0.31 \\
\hline Biddulphia sp. & $6.9 \times 10^{3}$ & $1.5 \times 10^{2}$ & 5.2 & $3.8 \times 10^{4}$ & 1.23 \\
\hline Chaetoceros cinctum ". & $1.9 \times 10^{1}$ & 3.7 & 5.9 & $1.3 \times 10^{2}$ & 0.08 \\
\hline Chaetoceros didymus. & $1.7 \times 10^{2}$ & $3.3 \times 10^{1}$ & 5.9 & $5.7 \times 10^{2}$ & 0.10 \\
\hline Chaetoceros gracile & $2.0 \times 1.0^{1}$ & 3.0 & 7.8 & $2.2 \times 10^{2}$ & 0.06 \\
\hline Chaetoceros septentrionalis ". & $1.2 \times 10^{1}$ & 2.0 & 6.6 & $9.1 \times 10^{1}$ & 0.25 \\
\hline Chaetoceros socialis & $2.8 \times 10^{1}$ & 5.1 & 6.5 & $1.9 \times 10^{2}$ & 0.01 \\
\hline Coscinodiscus radiatus & $2.1 \times 10^{4}$ & $2.8 \times 10^{3}$ & 8.9 & $2.2 \times 10^{5}$ & 1.76 \\
\hline Coscinodiscus wailesi & $6.6 \times 10^{3}$ & $9.3 \times 10^{2}$ & 8.2 & $2.9 \times 10^{5}$ & 1.09 \\
\hline Coscinodiscus sp. & $2.1 \times 10^{2}$ & $3.9 \times 10^{1}$ & 6.3 & $1.3 \times 10^{5}$ & 0.90 \\
\hline Cylindropyxis profunda & $1.2 \times 10^{1}$ & 2.0 & 6.6 & $8.8 \times 10^{1}$ & 0.20 \\
\hline Ditylum brightwellii & $2.4 \times 10^{3}$ & $2.6 \times 10^{3}$ & 8.2 & $2.6 \times 10^{4}$ & 0.53 \\
\hline Melosira sp. $\cdots$ & $8.9 \times 10^{1}$ & $1.8 \times 10^{1}$ & 5.8 & $6.7 \times 10^{3}$ & 0.31 \\
\hline Nitzschia delicatissima $\cdots$ & 6.0 & 1.1 & 6.2 & $4.6 \times 10^{1}$ & 0.30 \\
\hline Nitzschia longissima & $1.9 \times 10^{1}$ & 3.2 & 7.0 & $9.2 \times 10^{1}$ & 0.13 \\
\hline Nitzschia pungens" & $3.5 \times 10^{1}$ & 6.9 & 5.8 & $3.3 \times 10^{2}$ & 0.20 \\
\hline Phaeodactylum tricornutum & $1.7 \times 10^{1}$ & 2.8 & 7.0 & $6.1 \times 10^{1}$ & 0.02 \\
\hline Skeletonema costatum & $1.6 \times 10^{1}$ & 2.8 & 6.6 & $6.7 \times 10^{1}$ & 0.04 \\
\hline Stephanopyxis turris & $1.1 \times 10^{3}$ & $1.6 \times 10^{2}$ & 6.8 & $5.8 \times 10^{4}$ & 1.00 \\
\hline Thalassiosira nordenskioldii ${ }^{*}$ & $4.9 \times 10^{2}$ & $8.8 \times 10^{1}$ & 6.6 & $4.1 \times 10^{3}$ & 0.70 \\
\hline Thalassiosira pacifica ${ }^{\circ}$ & $7.3 \times 10^{2}$ & $1.4 \times 10^{2}$ & 6.1 & $6.5 \times 10^{3}$ & 0.35 \\
\hline Thalassiosira polycorda ${ }^{-}$ & $7.7 \times 10^{2}$ & $1.2 \times 10^{2}$ & 7.3 & $1.2 \times 10^{4}$ & 0.26 \\
\hline Thalassiosira pseudonana. & $1.5 \times 10^{1}$ & 2.4 & 7.2 & $6.1 \times 10^{2}$ & 0.07 \\
\hline Thalassiosira weissflogii & $1.2 \times 10^{2}$ & $2.0 \times 10^{1}$ & 6.0 & $7.2 \times 10^{2}$ & 0.04 \\
\hline Thalassiosira sp. & 5.0 & $9.6 \times 10^{1}$ & 6.0 & $1.8 \times 10^{1}$ & 0.01 \\
\hline \multicolumn{6}{|l|}{ Prymnesiophyceae } \\
\hline Cricosphaera carterae & $1.0 \times 10^{2}$ & $1.6 \times 10^{1}$ & 7.8 & $4.1 \times 10^{2}$ & 0.03 \\
\hline Pavlova lutheri & $4.0 \times 10^{1}$ & 8.0 & 5.0 & $4.1 \times 10^{1}$ & 0.01 \\
\hline \multicolumn{6}{|l|}{ Dinophyceae } \\
\hline Amphidinium carterae & $9.6 \times 10^{1}$ & $1.8 \times 10^{1}$ & 6.3 & $3.2 \times 10^{2}$ & 0.07 \\
\hline \multicolumn{6}{|l|}{ Chlorophyceae } \\
\hline Dunaliella tertiolecta & $3.6 \times 10^{1}$ & 6.1 & 6.9 & $1.3 \times 10^{2}$ & 0.01 \\
\hline
\end{tabular}

rate and the cell carbon quota (Fig. 1a) is described by the linear equation $\psi=8.7 \cdot 10^{-5}\left(\mathrm{pgC} \mathrm{cell}^{-1}\right)+0.22$, $F=50.9^{\cdots}$. A similar relationship is apparent between sinking rate and cell nitrogen quota (Fig. 1b), and is described by the equation $\psi=3.9 \cdot 10^{-4}\left(\operatorname{pgN} \mathrm{cell}^{-1}\right)+$ $0.24, F=16.0^{\circ}$. Sinking rates were also linearly correlated with cell (or particle) volume (Fig. 1C), and were described by the equation $\psi=5.1 \cdot 10^{-6}\left(\mu \mathrm{m}^{3} \mathrm{cell}\right.$ volume) $+0.21, F=42.8^{\circ}$. The source data for each species used in these plots are compiled in Table 1. Sinking rates were low $\left(\bar{\psi}=0.13 \mathrm{~m} \mathrm{~d}^{-1}\right)$ among species having cell quotas $<5 \cdot 10^{2} \mathrm{pg} \mathrm{C}$ cell ${ }^{-1}$ or $<9 \cdot 10^{1} \mathrm{pg} \mathrm{N}$ cell ${ }^{-1}$. The co-variation is most evident in species having cell quotas greater than these values.

Since the $\mathrm{C}_{\text {cell }}^{-1}$ and $\mathrm{N}^{-1} \mathrm{Cll}^{-1}$ ratios are also correlated with cell volume $(P<0.001)$, it is not surprising that they are correlated with sinking rates. This correlation is thought to be coincidental rather than causa- tive. The co-variation may be explained by the fact that these quotas are simply indices of cell size. Nonetheless, the reported correlations between $\psi$ and the cell carbon and nitrogen quotas may be very useful in the application of (sinking rate) loss parameters to modelling efforts wherein carbon and nitrogen are budgeted. Since the silicon content of diatoms is similarly correlated with cell size (Paasche, 1973), it would be valuable to define the proportionality between sinking rate and silica per cell quotas.

Data from the 29 species were also examined for relationships between $\psi$ and the volume-normalized quotas (i.e. $\mathrm{pgC} \mu \mathrm{m}^{-3}$ and $\mathrm{pgN} \mu \mathrm{m}$ ); this analysis showed no significant $(P>0.10)$ correlation between $\psi$ and these indicies. The absence of correlation indicates the $\psi$ differences among species were not due to differences in the intracellular mass densities of carbon or nitrogen per se; this is taken as supportive 

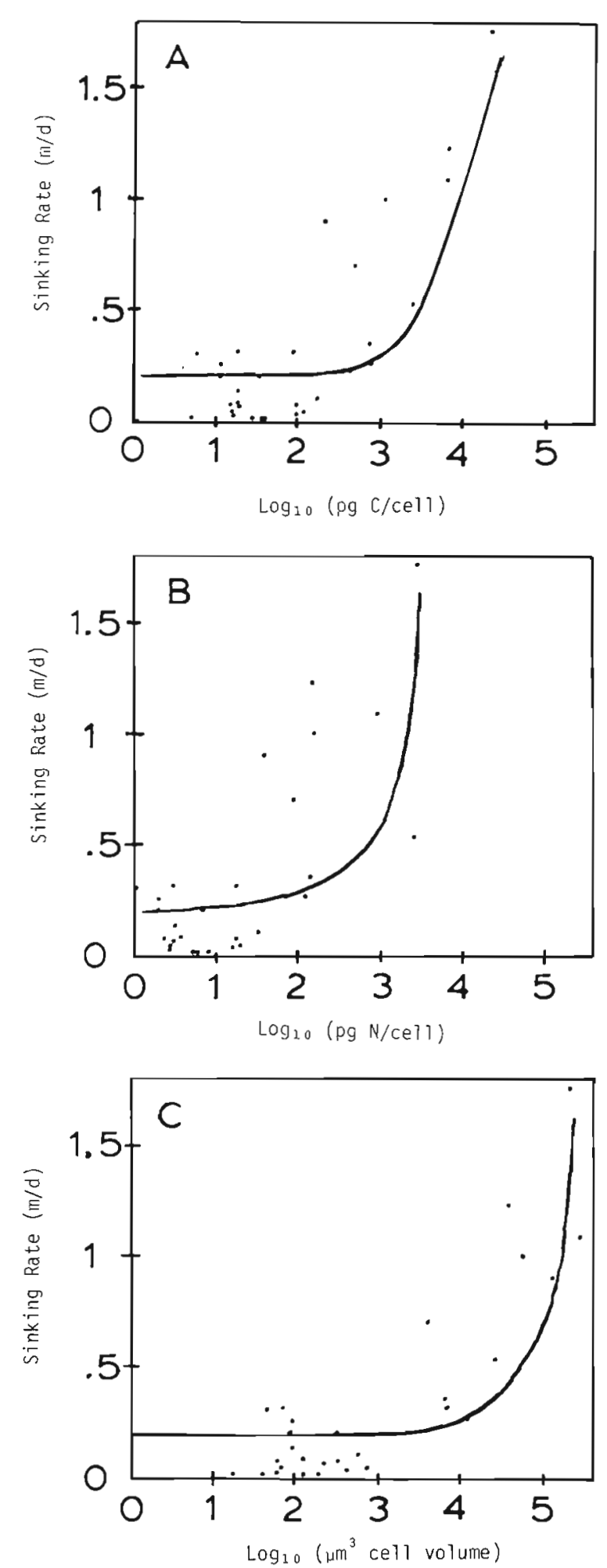

Fig. 1. Sinking rates $\left(\mathrm{m} \mathrm{d}^{-1}\right)$ as a function of (A) carbon cell quota, (B) nitrogen cell quota, (C) cell volume for the 29 species of marine phytoplankton grown under nutrientreplete conditions. Specific data for each species are given in Table 1. Curves drawn through the semi-log distributions of points reprensent the linear regression equations describing each data set evidence that the observed $\psi$-cell quota relationships are coincidental with the co-variation of these quotas with cell size. We also found no relationship between the $\mathrm{C} / \mathrm{N}$ ratio and cell volume in these nutrient-replete cultures; similar observations were made by Blasco et al. (1982).

Physiological processes such as photosynthesis (e.g. Taguchi, 1976), respiration and growth rate (e.g. Banse, 1976), have been shown to vary with cell size. Since the sinking rate of phytoplankton is a physical manifestation of both hydrodynamic and physiological conditions of the particle, a relationship between $\psi$ and particle volume is expected. In these trials, phytoplankton sinking rates appear to be linearly related to their cell volumes (Fig. 1c).

These results, concerning the sinking rate with cell size co-variation, differ somewhat from the data of Eppley et al. (1967) and Smayda (1970), and indicate generally lower sinking rates for cells of a given species/size. The higher rates observed in previous works are thought to be related to the manner in which the rates were computed; computational methods used in previous works can result in systematic over-estimates of the population mean sinking rate (Bienfang et al., 1977) Moreover, previous works dealt with a fewer number of species, and mostly the larger net-plankton sizes. Thus, a portion of the apparent differences between this and previously reported data sets probably reflects the number of species, and range of particle sizes examined. Also, the earlier works reported an exponential correlation between sinking rate and cell size when diameter was used as the index of cell size. The linear $\psi$ with cell size co-variation, described here, uses cell volume as the size index.

Our results of this work provide useful approximations of the sinking rates of net-and nanoplanktonic organisms under conditions of active metabolism. The distinction between these size classes is conventionally made at the $20 \mu \mathrm{m}$ size interval. Species examined in this study considered nanoplankton had the following characteristics: $<5 \times 10^{3} \mu \mathrm{m}^{3}$ cell volume, $<20 \mu \mathrm{m}$ equivalent spherical diameter, $<5 \times 10^{2} \mathrm{pgC}$ cell ${ }^{-1}$ and $<9 \times 10^{1} \mathrm{pgN}$ cell ${ }^{-1}$. Average sinking rate was low $\left(\psi=0.13 \mathrm{md}^{-1}\right)$ and relatively invariant among nanoplankton of various sizes and phyletic classifications. Given the number and density of species represented, this rate is probably a good estimate for actively growing nanoplanktonic organisms. The analysis of data for organisms only in the netplankton size class yielded $\psi$ - cell size relationships which were lightly different quantitatively than those computed across all species. For only the netplankton species, sinking rates $\left(\mathrm{m} \mathrm{d}^{-1}\right)$ were related to cell size indicies as follows: $\psi=6.2 \times 10^{-5}\left(\mathrm{pgC} \mathrm{cell}^{-1}\right)+0.56$; $\psi=2.0 \times 10^{-4}\left(\mathrm{pgN}\right.$ cell $\left.{ }^{-1}\right)+0.67 ;$ and $\psi=3.3 \times 10^{-6}$ 
$\left(\mu \mathrm{m}^{3}\right.$ cell volume) +0.55 . The average sinking rate of organisms in the netplankton size class was $0.71 \mathrm{~m} \mathrm{~d}^{-1}$. Given the potentially large range of cell size in this category, this estimate is probably subject to greater variability than that for the nanoplankton. The size structure of phytoplankton assemblages in nature can have important consequences to the settling losses of photoautotrophic biomass. These values, together with information on the quantitative importance of these 2 size classes, may be useful in the prudent estimation of vertical transport rates of phytoplankton biomass in various natural systems.

Acknowledgements. This research was supported by Grants OCE-7819234 and OCE-8100679 from the US National Science Foundation, and by the Natural Sciences and Engineering Research Council of Canada. We thank Ms. Lynne Quarmby, Molly Morrison, and Alexis Cheong Linder for technical assistance.

\section{LITERATUR CITED}

Banse, K. (1976). Rates of growth, respiration, and photosynthesis of unicellular algae as related to cell size-a review. J. Phycol. 12: 135-140

Bienfang, P. K. (1981a). Sinking rate dynamics of Cricosphaera carterae Braarud. I. Effects of growth rate, limiting substrate, and diurnal variation in steady-state populations. J. exp. mar. Biol. Ecol. 49: 217-233

Bienfang, P. K. (1981b). SETCOL - a technologically simple and reliable method for measuring phytoplankton sinking rates. Can. J. Fish. Aquat. Sci. 38: 1289-1294

Bienfang, P. K., Harrison, P. J., Quarmby, L. M. (1982). Sinking rate response to depletion of nitrate, phosphate, and silicate in four marine diatoms. Mar. Biol. 67: 295-302

Bienfang, P. K., Johnson, W., Laws, E. (1977). Phytoplankton sinking rate determination: technical and theoretical aspects, an improved methodology. J. exp. mar. Biol. Ecol. 30: $283-300$

Blasco, D., Packard, T T., Garfield, P. C. (1982). Size dependence of growth rate, respiratory electron transport system activity, and chemical composition in marine diatoms in the laboratory. J. Phycol. 18: 58-63

Eppley, R. W., Holmes, R. W., Strickland, J. D. H. (1967). Sinking rates of marine phytoplankton measured with a fluorometer. J. exp. mar. Biol. Ecol. 1: 191-208

Gordon, Jr, D. C. (1969). Examination of methods of particulate organic carbon analyses. Deep Sea Res. 16: 661-665

Harrison, P. J., Waters, R. E., Taylor, F. J. R. (1980). A broad spectrum artificial seawater medium for coastal and open ocean phytoplankton. J. Phycol. 16: 28-35

Paasche, E. (1973). The influence of cell size on growth rate, silica content, and some properties of four marine centric diatom species. Norw. J. Bot. 20: 197-204

Smayda, T. J. (1970). The suspensions and sinking of phytoplankton in the sea. Oceanogr. mar. Biol. Rev. 8: 353-414

Smayda, T. J., Boleyn, B. J. (1965). Experimental observations on the flotation of marine diatoms. I. Thalassiosira $c . f$. nana, Thalassiosira rotula and Nitschia seriata. Limnol. Oceanogr. 10: 499-509

Taguchi, S. (1976). Relationship between photosynthesis and cell size of marine diatoms. J. Phycol. 12: 185-189

Titman, D. (1975). A fluorometric technique for measuring sinking rates of freshwater phytoplankton. Limnol Oceanogr. 20: 869-875

Accepted for printing on May 25, 1983 